\title{
Transforming Growth Factor-Beta (TGF-B) Regulates Nerve Growth Factor and Cyclooxygenase-2 Expression in Subsynovial Connective Tissue in Patients with Carpal Tunnel Syndrome
}

\author{
Mitsufumi Nakawaki ${ }^{1}$, Kentaro Uchida ${ }^{1 *}$, Kenji Onuma ${ }^{1}$, Koji Sukegawa ${ }^{1}$, Toshihide \\ Matsumoto $^{2}$, Gen Inoue ${ }^{1}$, Hiroyuki Sekiguchi ${ }^{3}$ and Masashi Takaso ${ }^{1}$ \\ ${ }^{1}$ Department of Orthopedic Surgery, Kitasato University School of Medicine, Sagamihara City, Japan \\ ${ }^{2}$ Department of Pathology, Kitasato University School of Medicine, Sagamihara City, Japan \\ ${ }^{3}$ Shonan University of Medical Sciences Research Institute, Chigasaki City, Japan
}

*Corresponding author: Kentaro Uchida, Department of Orthopedic Surgery, Kitasato University School of Medicine, 1-15-1 Minami-ku Kitasato, Sagamihara City, Kanagawa 252-0374, Japan

\begin{abstract}
Background: It has been reported that transforming growth factor-beta (TGF- $\beta$ ) is elevated in the subsynovial connective tissues (SSCTs) of patients with idiopathic carpal tunnel syndrome (CTS) and TGF- $\beta$ induced fibrosis of SSCTs. A TGF- $\beta$-mediated pathway may be a potential target for CTS therapy. Cycloxygenase-2 (COX-2) and nerve growth factor (NGF) are regulated by TGF- $\beta$ and are associated with fibrosis in several tissues; however, regulation in SSCTs has not been fully clarified.

Methods: Forty-three SSCTs were sampled from 35 patients undergoing carpal tunnel release (CTR) surgery. Correlation between TGF- $\beta$ mRNA and protein expression and COX-2 and NGF were evaluated using quantitative PCR (q-PCR) analysis of total RNA sampled from the SSCTs. To investigate regulation of COX-2 and NGF by TGF- $\beta$, cultured SSCT cells were stimulated with TGF- $\beta$ and COX-2 and NGE mRNA and protein expression were evaluated using q-PCR and western blotting.

Results: TGF- $\beta$-, NGF-, and COX-2-positive cells were observed in SSCTs. Expression of COX-2 and NGF positively correlated with TGF- $\beta$ mRNA expression in the SSCTs of CTS patients (COX-2, $r=0.629, p<0.001$; NGF, $r=0.521$, $p<0.001)$. The expression of COX-2 and NGF mRNA and protein increased significantly in SSCT cells following exogenous treatment with TGF- $\beta$ compared to vehicle-treated cells $(p<0.05)$.
\end{abstract}

Conclusions: TGF- $\beta$ may regulate COX- 2 and NGF in the SSCTs of CTS patients.

\section{Keywords}

Subsynovial connective tissues, Transforming growth factor- $\beta$, Nerve growth factor, Cycloxygenase-2

\section{Introduction}

Carpal tunnel syndrome (CTS) is a common neuropathy encountered in orthopedics. It results from compression of the distal median nerve (MN) within the carpal tunnel. Characteristic complaints of CTS are numbness, paresthesia, and pain in the hand and fingers, often exacerbated at night [1]. This characteristic MN compression results in various degrees of disability $[2,3]$. In recent years, elucidation of the pathological condition has progressed; however, the mechanism is still unknown.

Transforming growth factor- $\beta$ (TGF- $\beta$ ) plays an important role in fibrotic reactions [4]. TGF- $\beta$ levels are increased in injured tissues, and excessive TGF- $\beta$ production has induced fibrosis in several tissues $[4,5]$. In the wrist, Subsynovial connective tissue (SSCT) envelops the nine flexor tendons and the $\mathrm{MN}$ in the carpal tunnel. Recent studies have shown that increased fibrosis of SSCT contributes to CTS development and is involved in the median nerve compression [6-9]. Increased TGF- $\beta$ expression has been observed in the SSCT of patients with idiopathic CTS [10] and fibrosis is associated with

Citation: Nakawaki M, Uchida K, Onuma K, Sukegawa K, Matsumoto T, et al. (2018) Transforming Growth Factor-Beta (TGF-B) Regulates Nerve Growth Factor and Cyclooxygenase-2 Expression in Subsynovial Connective Tissue in Patients with Carpal Tunnel Syndrome. Int Arch Orthop Surg 1:002. Accepted: September 17, 2018; Published: September 19, 2018

Copyright: (c) 2018 Nakawaki M, et al. This is an open-access article distributed under the terms of the Creative Commons Attribution License, which permits unrestricted use, distribution, and reproduction in any medium, provided the original author and source are credited. 
Table 1: Primers sequences in this study.

\begin{tabular}{|l|l|l|}
\hline Primer & Sequence (5'-3') & $\begin{array}{l}\text { Product size } \\
\text { (bp) }\end{array}$ \\
\hline COX-2-F & TGGCTGAGGGAACACAACAG & 74 \\
\hline COX-2-R & AACAACTGCTCATCACCCCA & \\
\hline NGF-F & CCCATCCCATCTTCCACAGG & \multirow{2}{*}{74} \\
\hline NGF-R & GGTGGTCTTATCCCCAACCC & \\
\hline GAPDH-F & TGTTGCCATCAATGACCCCTT & \multirow{2}{*}{202} \\
\hline GAPDH-R & CTCCACGACGTACTCAGCG & \multicolumn{1}{|l}{} \\
\hline
\end{tabular}

elevated activity of TGF- $\beta$ [9]. Therefore, TGF- $\beta$-mediated pathway may be important in CTS pathology, albeit that its mechanism is not fully understood.

Recent studies have reported that TGF- $\beta$ stimulates molecules involved in pain, including cycloxygenase-2 (COX-2) and nerve growth factor (NGF) in smooth muscle cells,[11] epithelial cells, [12] and the articular cartilage of osteoarthritis patients [13]. Notably, a range of studies have reported that COX-2 and NGF may contribute to liver and cystic fibrosis [14]. TGF- $\beta$-mediation of these pathways may be a potential target for CTS therapy; however, regulation of COX- 2 and NGF by TGF- $\beta$ in SSCTs has not been examined.

Here, we investigated TGF- $\beta$ regulation of $\mathrm{COX}-2$ and NGF using SSCT harvested from CTS patients.

\section{Materials and Methods}

Human recombinant TGF- $\beta$ was obtained commercially from R\&D Systems, Inc. (Minneapolis MN, USA). Rabbit polyclonal primary antibodies against COX-2 (cat. no. ab52237) and rabbit monoclonal primary antibodies against NGF (cat.no. ab52918) were purchased from Abcam (Cambridge, UK).

We performed an unregistered retrospective study to investigate the correlation between the gene expressions of SSCTs. This study received approval from the Ethics Review Board of Kitasato University (reference number: KMEO B13-113). Consent to participation was provided by the patients for collection of SSCTs for examination. Inclusion criteria included a clear diagnosis of CTS, a neural electrophysiological examination conducted in the outpatient department of our hospital, and subsequent treatment by carpal tunnel release (CTR) surgery (CTRS). A total of 35 patients with CTS underwent carpal tunnel release CTRS at our center. The study included 12 men and 23 women aged 38-87 years (mean \pm SD, $68.3 \pm 10.9$ years) with a mean \pm SD body mass index (BMI) of $24.0 \pm 5.8 \mathrm{~kg} / \mathrm{m}^{2}$ (range 13.6-44.0). A sample of 43 SSCT was harvested from each operated hand during the CTR. A portion of 35 SSCT tissue samples was kept at $-80^{\circ} \mathrm{C}$ until use in RNA extraction for real-time PCR analysis. SSCT from eight patients were additionally utilized for cell culture. The remaining tissue samples were used for immunohistochemistry. Each patient provided their informed consent to inclusion in the study the day preceding surgery.

Total RNA was obtained from the sampled SSCT by use of TRIzol reagent (Invitrogen, Carlsbad CA, USA) as described previously $[15,16]$. cDNA was synthesized using SuperScript III RT (Invitrogen) in accordance with the manufacturer's protocol. The primers were developed by use of the Primer Blast software and synthesized at Hokkaido System Science Co., Ltd. (Sapporo, Japan). PCR primer pair sequences are provided in Table 1. Specificity of the amplified products was evaluated with the use of melt curve analysis, while quantitative PCR was conducted with the Real-Time PCR Detection System (CFX-96; Bio-Rad, Richmond CA, USA) to determine relative levels of mRNA expression. mRNA expression was normalized against GAPDH mRNA levels.

To investigate whether TGF- $\beta$ regulates COX- 2 and NGF expression in SSCT, cells from the SSCTs of six CTS patients were isolated from SSCT by digestion of the tissue with $5 \mathrm{~mL}$ of $1 \mathrm{mg} / \mathrm{mL}$ type I collagenase solution. The obtained cells were cultured in minimum essential medium alpha ( $\alpha$-MEM) supplemented with $10 \%$ fetal bovine serum in six-well plates. After 7 days, the cells were exposed to 1 and $10 \mathrm{ng} / \mathrm{mL}$ human recombinant TGF- $\beta$ for $24 \mathrm{~h}$. Controls were exposed to culture medium without TGF- $\beta$. Following treatment, the cells were collected for isolation RNA (see above), and COX-2 and NGF expression was evaluated using RT-PCR. Cells were also collected and subject to protein extraction (described below), and COX-2 and NGF protein expression was analyzed by western blotting.

To investigate COX-2 and NGF protein expression, SSCT cells stimulated with 1 or $10 \mathrm{ng} / \mathrm{mL}$ TGF- $\beta$ were lysed in radioimmune precipitation buffer (RIPA) (Wako Pure Chemical, Tokyo, Japan) supplemented with a protease inhibitors (Sigma-Aldrich, MO, USA. Protein concentrations of the tissue extracts were then measured by a commercial bicinchoninic acid assay kit (Pierce, Rockford Illinois, USA). Protein extracts (10 $\mu \mathrm{g} / \mathrm{lane})$ were then separated using sodium dodecyl sulfate-polyacrylamide gel electrophoresis. They were then electrophoretically transferred to a polyvinyl difluoride membrane and blocked for $1 \mathrm{~h}$ with a blocking reagent (Immunoblock, DS Pharma Biomedical Co., Ltd., Osaka, Japan). These blocked membranes were then incubated with rabbit primary antibodies against COX-2 and NGF at $4{ }^{\circ} \mathrm{C}$ overnight. The primary antibodies were diluted 1:1000 with blocking reagent. The membranes were then washed in tris-buffered saline (TBS-T) followed by incubation using horseradish peroxidase (HRP)-conjugated anti rabbit IgG antibodies (GE Healthcare, NJ, USA), following dilution at 1:1000 with blocking reagent. Immunoreactive proteins were visualized based on chemiluminescence using ECL substrate (Bio-Rad, Hercules, CA, USA), and images were visualized using X-ray film.

To reveal a normal distribution for this data, the Kolmogorov-Smirnov test were performed. Based on the results of this test, the relationship between TGF- $\beta$ and COX-2 and NGF was evaluated using Pearson's 

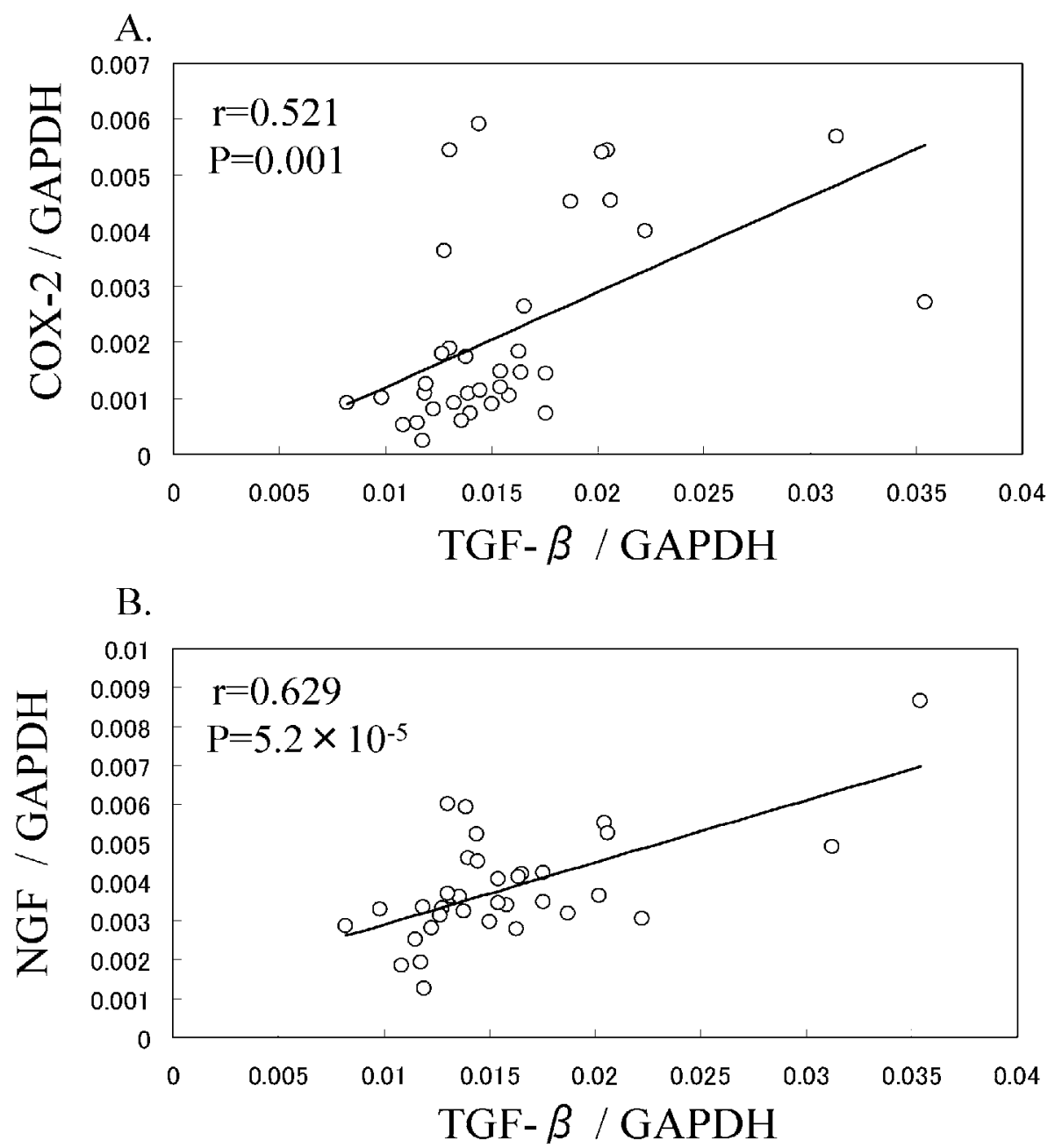

Figure 1: Correlation between mRNA expression levels of TGF- $\beta$ and COX-2 and NGF in subsynovial connective tissue. Correlation between TGF- $\beta$ and COX-2 (A) and NGF (B) mRNA expression levels in subsynovial connective tissue harvested from 35 CTS patients. "Pearson's coefficient $p<0.05$.

correlation coefficient. A $p<0.01$ was held to indicate statistical significance in correlation coefficient analysis. Potential statistical outliers that might have influenced linear regression coefficient analysis were identified with Cook's distance statistical test. Following the F-test, while differences between the vehicle control and TGF- $\beta$-treated SSCT cells were compared via oneway ANOVA using the Fisher least significant difference test. A $p<0.05$ was considered statistically significant. All statistical analyses were conducted using SPSS (v. 19.0; SPSS, Chicago IL, USA).

\section{Results}

The expression levels of TGF- $\beta$ were positively correlated with COX-2 (Figure $1 \mathrm{~A}, r=0.521, p<0.001$ ), Correlation between the TGF- $\beta$ mRNA expression and NGF mRNA expression levels were also detected (Figure 1B, $r=0.629, p<0.001$ ).

The effects of TGF- $\beta$ on the mRNA and protein expression of COX-2 and NGF were next examined. Real-time PCR analysis indicated that the gene expression of COX-2 and NGF was significantly raised in synovial cells in the presence of exogenous TGF- $\beta$ in comparison with vehicle control cells but was (Figure $2 \mathrm{~A}$ and Figure 2B). COX-2 and NGF protein expression also increased with exposure to TGF- $\beta$ (Figure 3).

\section{Discussion}

In this study of the mechanism of NGF and COX-2 regulation by TGF- $\beta$ in the SSCT of CTS patients, we detected correlations between TGF- $\beta$ concentration and NGF and COX-2 expression. Further, treatment cultured SSCT cells with TGF- $\beta$ increased the expression of NGF and COX-2. This suggests that TGF- $\beta$ regulates COX-2 and NGF in SSCT of CTS patients and may contribute to CTS pathology.

COX-2 upregulation was observed in CTS patients in the absence of inflammatory reactions and COX-2 mRNA expression in the synovium of CTS patients correlated with synovial hypertrophy [17]. Recent studies suggested that TGF- $\beta$ expression may be a therapeutic target for the therapy of the non-inflammatory fibrosis developed in CTS since its expression is increased $[10,18]$. Previous studies also reported that COX-2 was regulated by TGF- $\beta$ in granulosa cells, [19] fibroblasts, [20] and epithelial cells [12]. Hui, et al. reported that 
A.

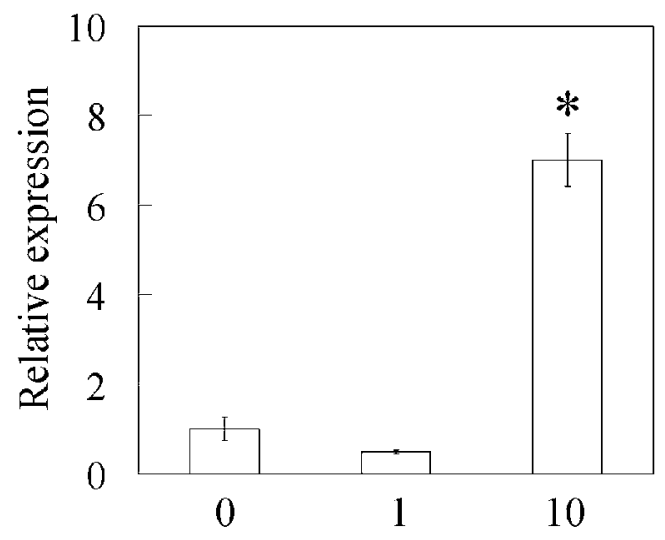

TGF- $\beta$ concentration $(\mathrm{ng} / \mathrm{ml})$
B.

$\mathrm{NGF}$

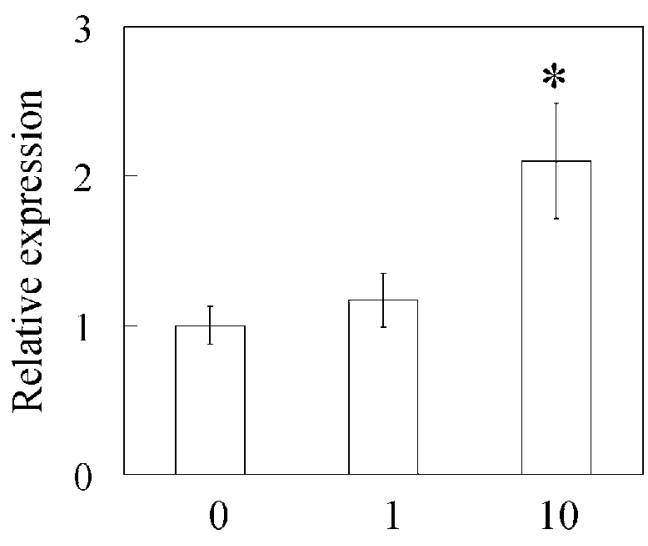

TGF- $\beta$ concentration (ng/ml)

Figure 2: Effect of TGF- $\beta$ on COX-2 and NGF mRNA expression in subsynovial connective tissue cell culture. Real-time polymerase chain reaction analysis for (A) cycloxygenase-2 (COX-2) and (B) Nerve growth factor (NGF).

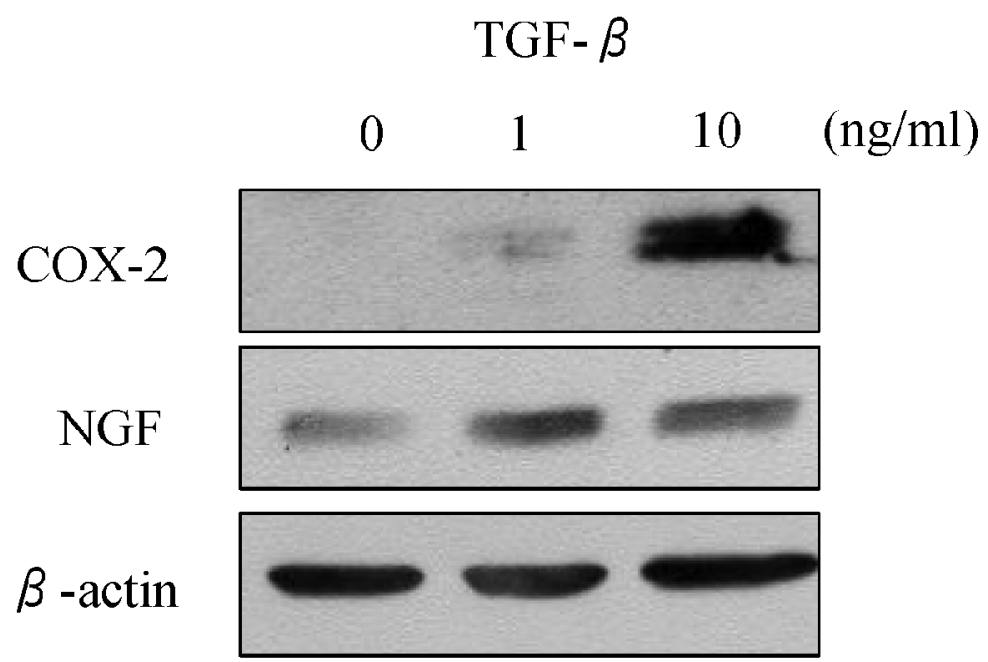

Figure 3: Effect of TGF- $\beta$ on COX-2 and NGF protein expression in subsynovial connective tissue cell culture.

Western blotting analysis for COX-2 and NGF. Subsynovial connective tissue cells were stimulated with 1 and $10 \mathrm{ng} / \mathrm{ml}$ TGF- $\beta$ for $24 \mathrm{~h}$ prior to protein extraction and analysis of COX-2 and NGF protein.

TGF- $\beta$ stimulates fibrosis via promotion of COX-2/PGE2 pathway in hepatic stellate cells [21] and that COX-2 inhibition reduced hepatic fibrosis. Here, there was a correlation between TGF- $\beta$ and COX-2, and exogenously added TGF stimulated COX-2 mRNA and protein expression in SSCT cells. Based on previous studies, our results suggest that TGF- $\beta$-mediated COX-2 elevation may contribute to fibrosis in SSCTS of CTS patients.

Several studies reported that NGF production and release were promoted by inflammatory cytokines, which include tumor necrosis factor-alpha (TNF- $a$ ) and interleukin-1-beta (IL-1 $\beta$ ) under inflammatory or non-inflammatory conditions by TGF- $\beta$, and that elevation of NGF contributes to musculoskeletal pain $[13,22-24]$. For example, TNF- $a$ and IL-1 $\beta$ promoted NGF mRNA expression in synovial cell culture [25]. TGF- $\beta$ stimulated NGF expression in osteoarthritic chondrocytes [13]. In contrast, NGF may exacerbate fibrosis in tissues such as liver, lung, and skin [25-27]. Micera, et al. reported that NGF promotes migration of lung and skin fibroblast and could exert a pro-fibrogenic effect [26]. NGF expression in hepatocytes during liver injury acts as a paracrine mediator for hepatic satellite cell-induced fibrosis [27]. Here, there was a correlation between TGF- $\beta$ and NGF, and exogenously added TGF stimulated NGF at both mRNA and protein level in SSCT cells. Our results suggest that NGF is also regulated by TGF- $\beta$ and may contribute to fibrosis in SSCTs of CTS patients.

Various clinical and clinical trials have demonstrated that COX-2 inhibitor and anti-NGF antibody show therapeutic efficacy in the treatment of pain in musculoskeletal disorders [28-31]. The non-steroidal anti-inflammatory drugs (NSAIDs) containing COX-2 inhibitors are among the most widely used classes of drugs for the acute and chronic pain management for musculoskeletal disorders [28]. NGF neutralization antibody also 
has also robust analgesic effects in osteoarthritis (OA) $[30,31]$ and low back pain $[29,31]$. Clinical trials of tanezumab in human OA patients and patients with low back pain are underway. In the present study, although we did not determine the association of COX-2 and NGF expression levels and pathology in CTS patients, findings concerning TGF- $\beta$-mediated COX- 2 and NGF regulation in SSCTS may be a target for future treatments of CTS.

Several limitations of our study deserve mention. First, the absence of a control, non-CTS patient population reduces the certainty of our results. The question of whether COX-2 and NGF levels are elevated in the SSCT of CTS patients as compared to non-CTS patients requires clarification. Second, histological examination of fibrosis and edema are needed to reveal the causative CTS pathology. Finally, we did not determine if a causative link exists between pathology and COX-2 and NGF in CTS patients.

\section{Conclusions}

TGF- $\beta$ may regulate COX- 2 and NGF in the SSCTs of CTS patients.

\section{Conflicts of Interest}

None to declare.

\section{References}

1. Phalen GS (1966) The carpal-tunnel syndrome. Seventeen years' experience in diagnosis and treatment of six hundred fifty-four hands. J Bone Joint Surg Am 48: 211-228.

2. Gelberman RH, Hergenroeder PT, Hargens AR, Lundborg GN, Akeson WH (1981) The carpal tunnel syndrome. A study of carpal canal pressures. J Bone Joint Surg Am 63: 380-383.

3. Zhao C, Ettema AM, Berglund LJ, An KN, Amadio PC (2011) Gliding resistance of flexor tendon associated with carpal tunnel pressure: A biomechanical cadaver study. J Orthop Res 29: 58-61.

4. Border WA, Noble NA (1994) Transforming growth factor beta in tissue fibrosis. N Engl J Med 331: 1286-1292.

5. Shah M, Foreman DM, Ferguson MW (1995) Neutralisation of TGF-beta 1 and TGF-beta 2 or exogenous addition of TGF-beta 3 to cutaneous rat wounds reduces scarring. J Cell Sci 108: 985-1002.

6. Donato G, Galasso O, Valentino P, Conforti F, Zuccalà V, et al. (2009) Pathological findings in subsynovial connective tissue in idiopathic carpal tunnel syndrome. Clin Neuropathol 28: 129-135.

7. Schuind F, Ventura M, Pasteels JL (1990) Idiopathic carpal tunnel syndrome: Histologic study of flexor tendon synovium. J Hand Surg Am 15: 497-503.

8. Neal NC, McManners J, Stirling GA (1987) Pathology of the flexor tendon sheath in the spontaneous carpal tunnel syndrome. J Hand Surg Br 12: 229-232.

9. Ettema AM, Amadio PC, Zhao C, Wold LE, An KN (2004) A histological and immunohistochemical study of the subsynovial connective tissue in idiopathic carpal tunnel syndrome. J Bone Joint Surg Am 86: 1458-1466.

10. Chikenji T, Gingery A, Zhao C, Passe SM, Ozasa Y, et al. (2014) Transforming growth factor-beta (TGF-beta) expres- sion is increased in the subsynovial connective tissues of patients with idiopathic carpal tunnel syndrome. J Orthop Res 32: 116-122.

11. Fong CY, Pang L, Holland E, Knox AJ (2000) TGF-beta1 stimulates IL-8 release, COX-2 expression, and PGE(2) release in human airway smooth muscle cells. Am J Physiol Lung Cell Mol Physiol 279: 201-207.

12. Liu M, Yang SC, Sharma S, Luo J, Cui X, et al. (2007) EGFR signaling is required for TGF-beta 1 mediated COX2 induction in human bronchial epithelial cells. Am J Respir Cell Mol Biol 37: 578-588.

13. Blaney Davidson EN, van Caam AP, Vitters EL, Bennink MB, Thijssen E, et al. (2015) TGF-beta is a potent inducer of Nerve Growth Factor in articular cartilage via the ALK5Smad2/3 pathway. Potential role in OA related pain? Osteoarthritis Cartilage 23: 478-486.

14. J Roca Ferrer, L Pujols, S Gartner, A Moreno, F Pumarola, et al. (2006) Upregulation of COX-1 and COX-2 in nasal polyps in cystic fibrosis. Thorax 61: 592-596.

15. Takano S, Uchida K, Inoue G, Minatani A, Miyagi M, et al. (2017) Increase and regulation of synovial calcitonin gene-related peptide expression in patients with painful knee osteoarthritis. J Pain Res 10: 1099-1104.

16. Minatani A, Uchida K, Inoue G, Takano S, Aikawa J, et al. (2016) Activation of calcitonin gene-related peptide signaling through the prostaglandin E2-EP1/EP2/EP4 receptor pathway in synovium of knee osteoarthritis patients. J Orthop Surg Res 11: 117.

17. Talmor M, Patel MP, Spann MD, Barden C, Specht M, et al. (2003) COX-2 up-regulation in idiopathic carpal tunnel syndrome. Plast Reconstr Surg 112: 1807-1814.

18. Gingery A, Yang TH, Passe SM, An KN, Zhao C, et al. (2014) TGF-beta signaling regulates fibrotic expression and activity in carpal tunnel syndrome $\mathrm{J}$ Orthop Res 32: 1444-1450.

19. Fang L, Chang HM, Cheng JC, Leung PC, Sun YP (2014) TGF-beta1 induces COX-2 expression and PGE2 production in human granulosa cells through Smad signaling pathways. J Clin Endocrinol Metab 99: 1217-1226.

20. Diaz A, Chepenik KP, Korn JH, Reginato AM, Jimenez SA (1998) Differential regulation of cyclooxygenases 1 and 2 by interleukin-1 beta, tumor necrosis factor-alpha, and transforming growth factor-beta 1 in human lung fibroblasts. Exp Cell Res 241: 222-229.

21. Hu KQ (2003) Cyclooxygenase 2 (COX2)-prostanoid pathway and liver diseases. Prostaglandins Leukot Essent Fatty Acids 69: 329-337.

22. Manni L, Lundeberg T, Fiorito S, Bonini S, Vigneti E, et al. (2003) Nerve growth factor release by human synovial fibroblasts prior to and following exposure to tumor necrosis factor-alpha, interleukin-1 beta and cholecystokinin-8: The possible role of NGF in the inflammatory response. Clin Exp Rheumatol 21: 617-624.

23. Manni L, Aloe L (1998) Role of IL-1 beta and TNF-alpha in the regulation of NGF in experimentally induced arthritis in mice. Rheumatol Int 18: 97-102.

24. Takano S, Uchida K, Miyagi M, Inoue G, Fujimaki H, et al. (2016) Nerve Growth Factor Regulation by TNF-alpha and IL-1beta in Synovial Macrophages and Fibroblasts in Osteoarthritic Mice. Journal of Immunology Research 2016: 5706359.

25. Dagnell C, Grunewald J, Kramar M, Haugom-Olsen H, Elmberger GP, et al. (2010) Neurotrophins and neurotrophin re- 
ceptors in pulmonary sarcoidosis - granulomas as a source of expression. Respir Res 11: 156.

26. Micera A, Vigneti E, Pickholtz D, Reich R, Pappo O, et al. (2001) Nerve growth factor displays stimulatory effects on human skin and lung fibroblasts, demonstrating a direct role for this factor in tissue repair. Proc Natl Acad Sci U S A 98: 6162-6167.

27. Oakley F, Trim N, Constandinou CM, Ye W, Gray AM, et al. (2003) Hepatocytes express nerve growth factor during liver injury: Evidence for paracrine regulation of hepatic stellate cell apoptosis. Am J Pathol 163: 1849-1858.

28. Atchison JW, Herndon CM, Rusie E (2013) NSAIDs for musculoskeletal pain management: Current perspectives and novel strategies to improve safety. J Manag Care Pharm 19: S3-S19.
29. Gimbel JS, Kivitz AJ, Bramson C, Nemeth MA, Keller DS, et al. (2014) Long-term safety and effectiveness of tanezumab as treatment for chronic low back pain. Pain 155: 1793-1801.

30. Sanga P, Katz N, Polverejan E, Wang S, Kelly KM, et al. (2013) Efficacy, safety, and tolerability of fulranumab, an anti-nerve growth factor antibody, in the treatment of patients with moderate to severe osteoarthritis pain. Pain 154: 1910-1919.

31. Tiseo PJ, Kivitz AJ, Ervin JE, Ren H, Mellis SJ (2014) Fasinumab (REGN475), an antibody against nerve growth factor for the treatment of pain: Results from a double-blind, placebo-controlled exploratory study in osteoarthritis of the knee. Pain 155: 1245-1252. 